\title{
EFFORTS TO IMPROVE BASIC MOVEMENT OF SHORT DISTANCE RUNNING USING DEMONSTRATION METHOD IN CLASS $V$ SD NEGERI 62 KOTA BENGKULU
}

\section{UPAYA MENINGKATKAN GERAK DASAR LARI JARAK PENDEK DENGAN MENGGUNAKAN METODE DEMONSTRASI PADA KELAS V SD NEGERI 62 KOTA BENGKULU}

\author{
Reza Kurnia Sandi ${ }^{1}$, Tito Parta Wibowo ${ }^{2}$ \\ ${ }^{1}$ Study Program Phsycal Education Study Program, Universitas Dehasen Bengkulu, \\ Indonesia \\ 2,Departemen Phsycal Education Study Program, Universitas Dehasen Bengkulu, \\ Indonesia
}

Corresponding Author: : Rezakurnia@gmail.com

\section{How to Cite :}

Sandi. R.K., Wibowo. T.P. (2020). Efforts To Improve Basic Movement Of Short Distance Running Using Demonstration Method In Class V SD Negeri 62 Kota Bengkulu. Hanoman Journal, 1(1).

\section{ARTICLE HISTORY}

Received [ $x x$ Month $x x x x$ ]

Revised [ $x x$ Month $x x x x$ ]

Accepted [xx Month $x x x x$ ]
Kata Kunci :

Metode Demonstrasi,

keterampilan gerak dasar sprint jarak pendek

\section{Keywords :}

Demonstration Method,

basic motion skills of shortdistance sprint
This is an open access article under the $C C-B Y-S A$ license

\begin{abstract}
ABSTRAK
Penelitian ini bertujuan untuk mengetahui peningkatan keterampilan gerak dasar sprint jarak pendek melalui pembelajaran olahraga dengan penerapan metode demonstrasi kepada siswa kelas lima di SD Negeri 62 Kota Bengkulu. Metode yang digunakan dalam penelitian ini adalah metode penelitian tindakan kelas. Populasi dalam penelitian ini adalah siswa kelas V di SD Negeri 62 Kota Bengkulu. Jumlah sampel adalah 20 siswa. Instrumen dalam penelitian ini adalah lembar observasi tentang sikap siswa sambil mengukur keterampilan gerak dasar sprint jarak pendek, peneliti menggunakan tes latihan lari jarak pendek 30 meter. Berdasarkan hasil, ditemukan bahwa ada peningkatan keterampilan gerak dasar sprint jarak pendek dari siswa kelas lima di SD Negeri 62 Kota Bengkulu melalui penerapan metode demonstrasi. Pada pra siklus menunjukkan persentase ketuntasan minimum $0 \%$ siswa yang tuntas di atas nilai rata-rata KKM, sedangkan pada siklus I diperoleh persentase ketuntasan minimal 45\% siswa di atas nilai KKM, dan pada siklus kedua diperoleh minimal persentase kelengkapan $85 \%$ siswa di atas rata-rata KKM. Dari hasil penelitian ini, dapat disimpulkan bahwa penerapan metode demonstrasi dapat meningkatkan keterampilan gerak dasar sprint jarak pendek pada siswa kelas lima di siswa kelas lima di SD Negeri 62 Kota Bengkulu.
\end{abstract}

\section{ABSTRACT}

This study aims to determine the improvement in the basic motion skills of short- distance sprint through sports learning by the application of demonstration methods to fifth grade students at SD Negeri 62 Bengkulu City. The method used in this study was a class action research method. The population in this study were fifth grade students at SD Negeri 62 Bengkulu City. Number of Samples were 20 students. The instrument in this study was an observation sheet on student's attitudes while measuring the basic motion skills of shortdistance sprint, the researcher used a 30 Meter short-distance sprint practice test. Based on the results, it was found that there was an improvement in the basic motion skills of shortdistance sprint of fifth grade students at SD Negeri 62 Bengkulu City through the application of demonstration methods. In the pre-cycle showed a minimum completeness percentage of $0 \%$ students who completed above the KKM average value, while in the cycle I obtained a minimum percentage of completeness of $45 \%$ students above the KKM value, and in the second cycle obtained a minimum percentage of completeness of $85 \%$ students above the KKM average. From the results of this study, it can be concluded that the application of the demonstration method can improve the basic motion skills of short-distance sprint in fifth grade students in fifth grade students at SD Negeri 62 Bengkulu City. 
kebugaran jasmani. Olahraga merupakan sebagian kebutuhan pokok dalam kehidupan sehari-hari karena dapat meningkatkan daya tahan tubuh seseorang. Olahraga dapat dimulai sejak usia dini hingga usia lanjut dan dapat dilakukan setiap hari. Jika seseorang melakukan olahraga secara rutin maka akan dapat meningkatkan massa ototnya, karena latihan tersebut dapat merangsang sel otot untuk tumbuh menjadi lebih besar dan sel-sel otot yang semula istirahat akan kembali menjadi aktif lagi.

Atletik merupakan olahraga tertua di dunia. Olahraga ini sangat terkenal pada masa kejayaannya, dimulai dari negara Yunani, negara-negara dibenua Eropa sampai Amerika dan seluruh dunia, masyarakat sangat antusias dan bersemangat dalam memainkannya. Dalam Olimpiade, atletik merupakan cabang olahraga yang memperebutkan banyak medali, hal ini muncul karena atletik mempunyai cabang olahraga yang banyak, terdiri dari 4 nomor yaitu; jalan, lari, lempar dan lompat. Dari tiap-tiap nomor tersebut di dalamnya terdapat beberapa nomor yang dilombakan. Untuk nomor lari terdiri dari: lari jarak pendek, jarak menengah, jarak jauh atau marathon, lari gawang, lari sambung dan lari lintas alam.

Seiring dengan berkembangnya zaman, olahraga atletik mulai kurang diperhatikan masyarakat. Ini dapat kita perhatikan dalam hal jumlah penonton yang mulai berkurang antusiasmenya untuk melihat perlombaan atletik, bahkan dalam setiap perlombaan atletik yang ada di dalam stadion hanya ada atlet itu sendiri dan para official. Ini berbanding terbalik dengan olahraga Sepak bola yang disetiap kursi stadion dipenuhi oleh suporter baik laki-laki maupun perempuan, dimana setiap pemain sepakbola bisa dihafal dan dikenal oleh masyarakat sementara untuk atletik kurang begitu dikenal dikalangan masyarakat.

Hal ini terjadi juga di dalam dunia pendidikan khususnya pendidikan jasmani karena daya minat siswa cukup besar pada olahraga permainan seperti olahraga dan bolavoli daripada olahraga atletik. Permendiknas No. 23 Tahun 2006 memberikan arti bahwa pendidikan jasmani olahraga dan kesehatan adalah bagian integral dari pendidikan keseluruhan yang bertujuan untuk mengembangkan aspek kebugaran jasmani, ketrampilan gerak, berfikir kritis, ketrampilan sosial, penalaran, stabilitas emosional, moral pola hidup sehat dan pengenalan lingkungan bersih melalui aktifitas jasmani dalam rangka mencapai tujuan pendidikan nasional. Olahraga dan pendidikan jasmani sering diartikan sebagai dua hal yang sama, akan tetapi olahraga dan pendidikan jasmani sebenarnya memiliki perbedaan yang signifikan. Berbeda dengan olahraga yang biasanya lebih bersifat kompetitif dan mengunggulkan prestasi, didalam pendidikan jasmani lebih diutamakan keterampilan proses dari pada pencapaian prestasi.

Penyelenggaraan pendidikan jasmani harus sesuai dengan tingkat perkembangan anak didik yang sedang belajar dan tugas ajar pun harus mampu mengakomodasi perubahan dan perbedaan karakteristik setiap individu serta mendorongnya ke arah perubahan yang lebih baik. Pengajaran langsung pada pendidikan jsmani memandang bahwa guru melakukan kontrol yang penuh terhadap apa yang siswa pelajari dan bagaimana prosesnya berlangsung.

Keberhasilan dalam proses pembelajaran sesungguhnya ditentukan oleh beberapa unsur, diantaranya sebagian ditentukan oleh kemampuan siswa itu sendiri, tenaga pendidik dan lingkungan. Guru selalu dihadapkan pada berbagai hal yang memerlukan pengambilan keputusan sehubungan dengan tugasnya baik sebelum, selama maupun sesudah terjadinya proses pembelajaran. Guru harus mengambil keputusan-keputusan tentang apa, bagaimana, kapan, untuk apa serta situasi dan kondisi belajar yang perlu diciptakan. Termasuk mengambil keputusan mengenai pelaksanaan rencana yang sudah dibuat, dan berhasil tidaknya 
pelaksanaan rencana yang telah dibuat. Berhasil tidaknya pelaksanaan pembelajaran dapat diketahui setelah diadakannya proses evaluasi. Hasil dari proses evaluasi dapat digunakan sebagai masukan dalam penyusunan dan pelaksanaan program pembelajaran selanjutnya.

Dalam pembelajaran penjas di sekolah dasar Atletik masuk dalam kurikulum pembelajaran, yaitu dengan kompetensi dasar. Mempraktikkan berbagai variasi gerak dasar ke dalam permainan dan olahraga dengan peraturan yang dimodifikasi serta nilai-nilai yang terkandung di dalamnya danstandar kompetensi. Mempraktikkan variasi gerak dasar ke dalam modifikasi atletik, serta nilai semangat, sportivitas, percaya diri dan kejujuran.

Dalam pengamatan awal yang dilakukan di SD Negeri 62 Kota Bengkulu, menunjukkan bahwa hasil belajar dalam bidang lari masih sangatlah kurang. Pada umumnya, siswa - siswi di sekolah tersebut merasa kesulitan dan berat dalam melakukan gerakan lari jarak pendek. Siswa juga menganggap lari jarak pendek ini kurang menarik untuk dilakukan. Bagi siswa putra lebih memilih permainan sepak bola, dan bagi siswa putri lebih memilih untuk melakukan permainan yang lain. Fasilitas dan alat penunjang olahraga lari di SD Negeri 62 Kota Bengkulu tidak sesuai dengan tahap pertumbuhan dan perkembangan siswa, hal ini tentu semakin memperparah keadaan pembelajaran lari disekolah tersebut. Selain hal itu, tidak sedikit siswa yang hanya duduk- duduk saja dan tidak aktif mengikuti pembelajaran lari .

Rendahnya motivasi siswa untuk melakukan aktivitas gerak dan kemampuan dasar lari jarak pendek tersebut, tidak terlepas dari faktor-faktor pendukung lain, diantaranya fasilitas yang terbatas, sekolah yang memiliki halaman yang sempit. Proses pembelajaran lari jarak pendek, guru memanfaatkan halaman, fasilitas serta belum adanya permainan yang menekankan pada langkah kaki dan kecepatan terbatas sehingga proses pembelajaran lari jarak pendek kurang maksimal. Hal tersebut ditunjukkan dengan masih banyaknya hasil belajar siswa tahun sebelumnya yang dibawah Kriteria Ketuntasan Minimal (KKM) yaitu 75. Sebanyak 11 siswa mendapatkan nilai diatas 75 atau berkategori tuntas dan sebanyak 16 siswa belum tuntas. Jika kondisi ini dibiarkan jelas akan berdampak buruk bagi siswa dalam proses dan hasil belajar selanjutnya.

Hambatan yang ada dalam proses pembelajaran lari jarak pendek tersebut, dapat dibantu dengan penggunaan media pembelajaran sebagai perantara dalam penyampaian informasi pesan dari intraksi yang terjadi antara guru dengan murid dalam upaya untuk mmeningkatkan efektivitas dan efisiensi pencapaian tujuan pembelajaran. Permasalahan yang dihadapi oleh para guru pendidikan jasmani adalah hal-hal yang berkaitan dengan sarana serta prasarana pendidikan jasmani sebagai media pembelajaran. Minimnya sarana dan prasarana pendidikan jasmani yang dimiliki sekolah- sekolah, menuntut seorang guru pendidikan jasmani untuk lebih kreatif dalam memberdayakan dan mengoptimalkan penggunaan sarana dan prasarana yang ada.

Pada proses pembelajaran Atletik khususnya lari di SD Negeri 62 Kota Bengkulu, guru hanya menggunakan metode ceramah, hal tersebut kurang mendukung terjadinya komunikasi, sehingga pesan yang disampaikan kurang begitu mengena. Teknik-teknik dalam teknik lari jarak pendek yang rumit sangat sulit dikuasai kalau hanya melihat dari contoh yang ada. Apalagi kadang-kadang guru dalam memberi contoh kurang begitu maksimal atau sempurna sehingga anak meniru seadanya saja. Dalam kaitannya dengan masalah ini guru kurang terobosan dalam masalah mengemas suatu bentuk model pembelajaran yang kreatif dan 
menyenangkan bagi anak sehingga proses pembelajaran dapat dengan mudah diserap oleh anak.

Peran guru Penjas dituntut agar bisa berfikir kreatif dan inovatif dalam menyajikan pembelajaran yang aktif dan menyenangkan bagi anak, sehingga pemilihan metode dan penggunaan alat yang tepat dapat membuat siswa akan semakin senang dan termotivasi dalam mengikti pembelajaran, juga dapat memudahkan Guru dalam penyampaian materi kepada siswa juga siswa dapat dengan mudah menangkap pesan yang disampaikan oleh guru. Penjelasan secara verbal yang seadanya belum dapat menghasilkan pemahaman siswa untuk melakukan gerak dasar lari jarak pendek dengan baik dan benar sehingga diperlukan model pembelajaran yang sesuai yang dapat membantu proses pembelajaran lari sehingga mampu mendapatkan hasil gerak dasar lari yang lebih baik. Dalam proses pembelajaran berlari yang dirancang dengan bentuk demonstrasi dirasa dapat merangsang anak untuk bergerak dan aktif sehingga diharapkan dapat membantu meningkatkan kemampuan siswa dalam pembelajaran lari jarak pendek serta dapat meningkatkan prestasi yang maksimal.

\section{LANDASAN TEORI Hakikat Pendidikan Jasmani}

Menurut Sukintaka (2004:30) bahwa Pendidikan Jasmani, Olahraga dan Kesehatan adalah proses interaksi antara peserta didik dan lingkungan melalui aktivitas jasmani untuk menuju manusia Indonesia seutuhnya. Sedangkan Engkos Kosasih (2005:4) mengatakan bahwa Pendidikan Jasmani, Olahraga dan Kesehatan ialah pendidikan yang mengaktualisasikan potensi aktivitas manusia yang berupa sikap tindak dan karya untuk diberi bentuk isi dan arah menuju kebulatan kepribadian sesuai dengan cita-cita kemanusiaan. Begitu juga menurut Harsuki (2003:5), Pendidikan Jasmani, Olahraga dan Kesehatan merupakan proses interaksi antara peserta didik dengan lingkungan, melalui aktivitas jasmani yang dikelola secara sistematik untuk menuju manusia Indonesia seutuhnya.

\section{Hakikat Pembelajaran}

Hamalik (2013:57), mengemukakan bahwa,"pembelajaran adalah kombinasi yang tersusun meliputi unsur-unsur manusiawi, material, fasilitas, perlengkapan dan prosedur yang saling mempengaruhi untuk mencapai tujuan pembelajaran"..

\section{Hakikat Atletik}

Atletik adalah olahraga yang tumbuh dan berkembang bersamaan dengan kegiatan alami manusia, berlari, meloncat, dan melempar adalah bagian yang tidak terpisahkan dari sejarah panjang kehidupan manusia, Muhajir (2016:100). Menurut Syarifudin (1992:2), atletik adalah satu cabang olahraga yang diperlombakan dan meliuti nomor-nomor jalan, lari, lompar, lompat dan loncat. Sehingga dapat dikatakan suatu perlombaan atletik akan terdapat lebih dari satu macam perlombaan. Sedangkan Purnomo dan Dapan (2011:1) menyatakan bahwa,"Atletik merupakan aktivitas jasmani yang terdiri dari gerakan-gerakan dasar yang dinamis, yaitu: jalan, lari, lompat, dan lempar".

\section{Hakikat Lari Jarak Pendek}

Menurut Muhajir (2016:108) bahwa lari cepat/sprint adalah perlombaan lari yang semua peserta berlari dengan kecepatan penuh dengan menempuh jarak 100 $\mathrm{m}, 200 \mathrm{~m}$, atau $400 \mathrm{~m}$. Kunci utama yang harus oleh pelari cepat adalah start atau tolakan. 


\section{METODE PENELITIAN}

Penelitian ini akan dilakukan sesuai dengan waktu pelajaran Penjas berlangsung yaitu Februari 2019, kegiatan dipusatkan di halaman sekolah dan di lapangan sepakbola SD Negeri 62 kota Bengkulu khususnya dalam pelaksanaan. Penentuan lokasi ini diharapkan memberi kemudahan khususnya menyangkut pengenalan lingkungan yang berhubungan dengan anak didik sebagai subjek penelitian atau menyangkut personil yang akan membantu dalam kelancaran kegiatan ini.

Desain penelitian yang digunakan dalam penelitian ini adalah Penelitian Tindakan Kelas dengan menggunakan siklus. Menurut Kristiyanto (2010: 18), tujuan penelitian tindakan kelas adalah untuk memperoleh cara meningkatkan atau memanipulasi perlakuan atau tindakan dalam pembelajaran pendidikan jasmani agar proses dan hasil pembelajaran pendidikan jasmani menigkat. Ada empat tahapan penting dalam penelitian tindakan kelas yaitu perencanaan (planning), tindakan (acting), pengamatan (observing), dan refleksi (reflecting) Kristiyanto (2010: 54). Keempat tahapan dalam penelitian tindakan kelas tersebut akan membentuk sebuah siklus. Jadi satu siklus dimulai dari tahap perencanaan sampai dengan refleksi. Banyaknya siklus dalam proses penelitian tindakan tergantung pada indikator pencapaian tindakan tercapai.

Populasi adalah wilayah generalisasi yang terdiri atas objek atau subjek yang mempunyai kualitas dan karakteristik tertentu yang ditetapkan oleh peneliti untuk dipelajari dan kemudian ditarik kesimpulannya Sugiyono (2005:21). Populasi dalam Penelitian ini adalah siswa kelas $\mathrm{V}$ yang terdiri atas 35 siswa. Terdiri atas 15 orang siswa putri dan 20 orang siswa putra. Dalam suatu proses penelitian, karena adanya perbedaan kategori keterampilan terhadap siswa putra dan putri maka peneliti hanya akan menajdikan siswa putra sebagai sampel dengan menggunakan metode purposive sampling. Maka sampel yang akan digunakan adalah sebanyak 20 orang siswa putra kelas V.

\section{HASIL}

\section{Gerak Dasar Lari Jarak Pendek Melalui Metode Demonstrasi Siswa Kelas V SD Negeri 62 Kota Bengkulu Sebelum Tindakan (Pra Siklus)}

Penelitian ini adalah penelitian tindakan kelas, peneliti dibantu oleh kolabolator penelitian yaitu Pipbri S,Pd selaku guru olahraga di SD Negeri 62 Kota Bengkulu. Terdapat empat tahap dalam setiap siklus penelitian ini, yaitu perencanaan pelaksanaan, observasi dan refleksi. Hasil dari tiap-tiap siklus digunakan sebagai refleksi untuk meningkatkan hasil yang lebih baik pada siklus berikutnya. Sebelum melakukan penelitian ini, peneliti mengumpulkan nilai pra siklus terlebih dahulu. Pengambilan data pra siklus pada hari Sabtu, 6 April 2019. Keterampilan gerak dasar lari jarak pendek siswa sebelum dilakukan tindakan dalam pembelajaran olahraga diambil dari hasil pengamatan dengan menggunakan lembar observasi.

Tabel 1. Hasil Pengamatan Pra Siklus: Lari Jarak Pendek
\begin{tabular}{|l|c|c|}
\hline \multicolumn{1}{|c|}{ Kriteria } & $\begin{array}{c}\text { Jumlah } \\
\text { siswa }\end{array}$ & $\begin{array}{c}\text { Persentase } \\
(\%)\end{array}$ \\
\hline Tuntas & 0 & $0 \%$ \\
\hline Tidak Tuntas & 20 & $100 \%$ \\
\hline Jumlah & 20 & $100 \%$ \\
\hline
\end{tabular}

14 | Reza Kurnia Sandi, Tito Parta Wibowo; Efforts To Improve Basic Movement... 
Dari hasil tes pra siklus yaitu belum terdapat satu siswa yang memiliki kriteria tuntas dengan persentase $0 \%$ dan sebanyak 20 siswa (100\%) yang belum memenuhi kriteria ketuntasan minimal. Hasil tersebut menunjukkan bahwa nilai tuntas siswa belum mencapai nilai indikator keberhasilan dalam pembelajaran. Hasil ini juga disimpulkan bahwa hasil pembelajaran gerak dasar lari jarak pendek siswa SD Negeri 62 Kota Bengkulu masih rendah, terlebih lagi, sebuah strategi atau teknik baru dalam pengajaran dibutuhkan untuk diaplikasikan agar menciptakan sebuah proses belajar yang lebih baik serta untuk meningkatkan keterampilan gerak dasar lari jarak pendek pada pembelajaran atletik. Oleh karena itu, penerapan model demonstrasi diharapkan mampu menyelesaikan masalah tersebut dan dapat meningkatkan gerak dasar lari jarak pendek Siswa kelas V SD Negeri 62 Kota Bengkulu. Untuk lebih jelasnya dapat dilihat dari gambar 1. di bawah ini:

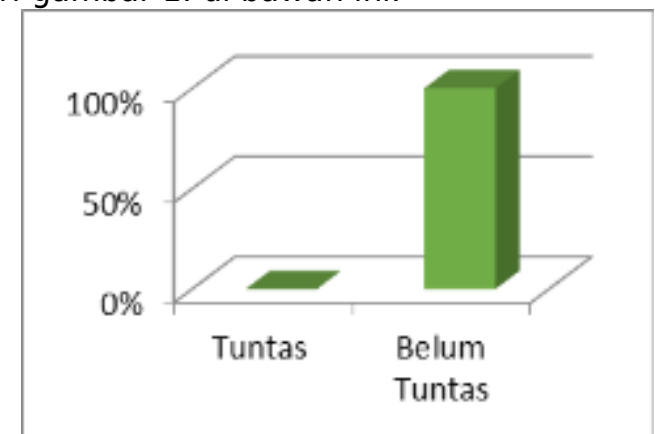

\section{Gambar 1. Tes Gerak Dasar Lari Jarak pendek Pada Pra-Siklus}

\section{Deskripsi Data Siklus 1}

Siklus 1 mulai dilakukan pada hari Selasa 9 April 2019, peneliti dibantu oleh kolabolator penelitian. Siklus ini terdiri dari empat langkah, yaitu perencanaan, pelaksanaan, observasi, dan refleksi. Penjelasan mengenai siklus 1 ini dijelaskan sebagai berikut :

Perencanaan Tindakan

Menyusun Rencana Pelaksanaan Pembelajaran (RPP), dengan kompetensi dasar yaitu Mempraktikkan variasi gerak dasar ke dalam modifikasi atletik, serta nilai semangat, seportivitas, percaya diri dan kejujuran

Guru mempersiapkan lembar observasi pembelajaran.

Mempersiapkan sarana dan alat yang akan digunakan, yaitu lapangan sebagai tempat pelaksanaan pembelajaran, bola, serta sarana pendukung lainnya.

Pelaksanaaan Tindakan

Pertemuan pertama dilaksanakan pada hari senin tanggal 9 April 2019 mulai dari jam 07.30 WIB sampai dengan jam 10.00 WIB sesuai dengan Rencana Pelaksanaan Pembelajaran (RPP) yang sudah disusun. Pertemuan pertama Siklus I yang dilakukan adalah pembelajaran gerak dasar lari cepat dengan langkah-langkah, sebagai berikut :

Kegiatan Awal

Guru membuka pelajaran dan mengajak siswa berdoa sesuai agama dan kepercayaan masing-masing.

1. Siswa dibariskan menjadi empat barisan

2. Mengecek kehadiran siswa

3. Menegur siswa yang tidak berpakaian lengkap

4. Melakukan gerakan pemanasan yang berorientasi pada kegiatan inti Kegiatan Inti 
Guru menjelaskan materi tentang gerak dasar lari jarak pendek yang memungkinkan materi tersebut dapat dipelajari siswa secara mandiri

Guru memberikan contoh dengan mendemonstrasikan sikap awalan sampai finish untuk teknik lari jarak pendek:

- Melakukan aba-aba dalam start

- Melakukan aba-aba"bersedia"

- Melakukan aba-aba"siap"

- Melakukan aba-aba"ya"

- Melakukan sikap yang benar pada saat lari

- Melakukan sikap lari pada waktu memasuki garis finish

Guru memberikan kesempatan bagi siswa untuk melakukan praktik secara individu. Guru melakukan evaluasi berupa tes parktik dari sikap awal, pelaksanaan, dan sikap akhir gerak dasar berlari kepada siswa secara individu.

Kegiatan Penutup

Bersama dengan siswa, guru menyimpulkan materi yang telah dilaksanakan.

Guru menutup pembelajaran

Pada tahap ini peneliti mengobservasi proses belajar mengajar di kelas semua data pada tahap ini dikumpulkan dengan menggunakan lembar observasi guru dan siswa.

Tabel 2. Rekapitulasi Hasil Observasi Kegiatan Siswa pada Siklus 1.

\begin{tabular}{|l|l|l|}
\hline Nomor & Kriteria & Skor \\
\hline 1 & Keaktifan & 3 \\
\hline 2 & Kerjasama & 2 \\
\hline 3 & Kesungguhan & 3 \\
\hline 4 & Percaya diri & 3 \\
\hline Jumlah & 11 \\
\hline \multicolumn{2}{|l|}{ Skor Maksimal } & 16 \\
\hline \multicolumn{2}{|l|}{ Persentase Keberhasilan } & $68,75 \%$ \\
\hline
\end{tabular}

Pada pertemuan siklus 1 , observasi kegiatan siswa dalam pembelajaran yang didapat oleh peneliti yaitu pada kriteria keaktifan diperoleh skor 3, kerjasama diperoleh skor 2, Kesungguhan skor 3, dan percaya diri diperoleh skor 3. Sehingga persentase keberhasilan siswa dalam sikap belajar sebesar 68,75\%. Selain dari lembar observasi siswa juga dilakukan melalui tes gerak dasar lari jarak pendek. Berikut hasil tes gerak dasar lari jarak pendek pada siklus 1:

Tabel 3. Hasil Pengamatan Pada Siklus I : Lari Jarak Pendek

\begin{tabular}{|l|c|c|}
\hline \multicolumn{1}{|c|}{ Kriteria } & Jumlah siswa & Persentase (\%) \\
\hline Tuntas & 9 & $45 \%$ \\
\hline Tidak Tuntas & 11 & $55 \%$ \\
\hline Jumlah & 20 & $100 \%$ \\
\hline
\end{tabular}

Dari hasil tes tahap siklus I yaitu terdapat 9 siswa yang memiliki kriteria tuntas dengan persentase $45 \%$ dan sebanyak 11 siswa (55\%) yang belum memenuhi kriteria ketuntasan minimal. Hasil tersebut menunjukkan bahwa nilai tuntas siswa belum mencapai nilai indikator keberhasilan dalam pembelajaran. Hasil ini juga disimpulkan bahwa hasil pembelajaran gerak dasar lari jarak pendek siswa SD Negeri 62 Kota Bengkulu masih rendah, terlebih lagi, sebuah strategi atau teknik baru dalam pengajaran dibutuhkan untuk diaplikasikan agar menciptakan sebuah proses belajar yang lebih baik serta untuk meningkatkan keterampilan gerak dasar lari jarak

16 | Reza Kurnia Sandi, Tito Parta Wibowo; Efforts To Improve Basic Movement... 
pendek pada pembelajaran atletik. Oleh karena itu, penerapan model demonstrasi diharapkan mampu menyelesaikan masalah tersebut dan dapat meningkatkan gerak dasar lari jarak pendek Siswa kelas V SD Negeri 62 Kota Bengkulu. Untuk lebih jelasnya dapat dilihat dari gambar 2. di bawah ini:

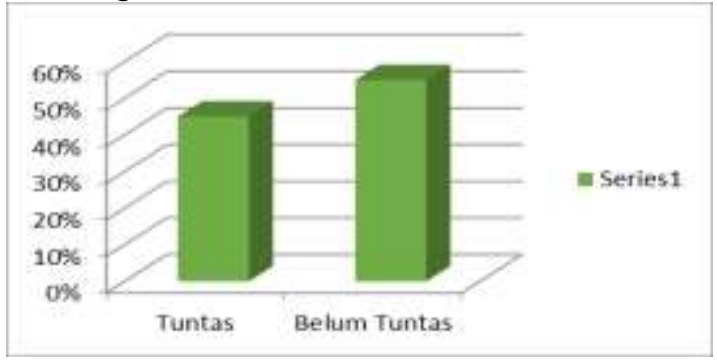

Gambar 2. Hasil Tes Gerak Dasar Lari Jarak Pendek Pada Tahap Siklus Refleksi

Dari hasil tes Gerak dasar lari jarak pendek menunjukan bahwa hanya 9 siswa dinyatakan memenuhi KKM ketuntasan dan 11 siswa dinyatakan tidak memenuhi KKM ketuntasan. Melalui refleksi dan pembahasan antara peneliti dan kolabolator penelitian, penerapan metode demonstrasi akan diajarkan lebih intensif dan efektif lagi pada siklus selanjutnya terutama pada aspek sikap akhir saat finish. Terlebih lagi, berdasarkan hasil observasi juga menunjukan bahwa pembelajaran gerak dasar lari cepat melalui penerapan metode demonstrasi pada siklus 1 ini belum maksimal, sehingga sangat perlu dilakukannya penelitian pada siklus berikutnya guna meningkatkan keterampialn gerak dasar lari jarak pendek.

\section{Deskripsi Data Siklus II}

Siklus II mulai dilakukan pada hari Selasa 16 April 2019, peneliti dibantu oleh kolabolator penelitian. Siklus ini terdiri dari empat langkah, yaitu perencanaan, pelaksanaan, observasi, dan refleksi. Penjelasan mengenai siklus 1 ini dijelaskan sebagai berikut :

Perencanaan Tindakan

Menyusun Rencana Pelaksanaan Pembelajaran (RPP), dengan kompetensi dasar yaitu Mempraktikkan variasi gerak dasar ke dalam modifikasi atletik, serta nilai semangat, seportivitas, percaya diri dan kejujuran

Guru mempersiapkan lembar observasi pembelajaran.

Mempersiapkan sarana dan alat yang akan digunakan, yaitu lapangan sebagai tempat pelaksanaan pembelajaran, bola, serta sarana pendukung lainnya.

Pelaksanaaan Tindakan

Pertemuan ketiga dilaksanakan pada hari Selasa 16 April 2019 mulai dari jam 07.30 WIB sampai dengan jam 10.00 WIB sesuai dengan Rencana Pelaksanaan Pembelajaran (RPP) yang sudah disusun. Pertemuan pertama Siklus II yang dilakukan adalah pembelajaran gerak dasar lari cepat dengan langkah-langkah, sebagai berikut

Kegiatan Awal

1. Guru membuka pelajaran dan mengajak siswa berdoa sesuai agama dan kepercayaan masing-masing.

2. Siswa dibariskan menjadi empat barisan

3. Mengecek kehadiran siswa

4. Menegur siswa yang tidak berpakaian lengkap

5. Melakukan gerakan pemanasan yang berorientasi pada kegiatan inti 
Kegiatan Inti

Guru menjelaskan materi tentang gerak dasar lari jarak pendek yang memungkinkan materi tersebut dapat dipelajari siswa secara mandiri

Guru memberikan contoh dengan mendemonstrasikan sikap awalan sampai finish untuk teknik lari jarak pendek:

1. Melakukan aba-aba dalam start

2. Melakukan aba-aba"bersedia"

3. Melakukan aba-aba"siap"

4. Melakukan aba-aba"ya"

5. Melakukan sikap yang benar pada saat lari

6. Melakukan sikap lari pada waktu memasuki garis finish

Guru memberikan kesempatan bagi siswa untuk melakukan praktik secara individu

Guru melakukan evaluasi berupa tes parktik dari sikap awal, pelaksanaan, dan sikap akhir gerak dasar berlari kepada siswa secara individu.

Kegiatan Penutup

Bersama dengan siswa, guru menyimpulkan materi yang telah dilaksanakan. Guru menutup pembelajaran

Pada tahap ini peneliti mengobservasi proses belajar mengajar di kelas semua data pada tahap ini dikumpulkan dengan menggunakan lembar observasi guru dan siswa.

Tabel 4. Rekapitulasi Hasil Observasi Kegiatan Siswa pada Siklus 1.

\begin{tabular}{|l|l|l|}
\hline Nomor & Kriteria & Skor \\
\hline 1 & Keaktifan & 4 \\
\hline 2 & Kerjasama & 3 \\
\hline 3 & Kesungguhan & 4 \\
\hline 4 & Percaya diri & 3 \\
\hline Jumlah & 14 \\
\hline \multicolumn{2}{|l|}{ Skor Maksimal } & 16 \\
\hline \multicolumn{2}{|l|}{ Persentase Keberhasilan } & $87,5 \%$ \\
\hline
\end{tabular}

Pada pertemuan siklus 2, observasi kegiatan siswa dalam pembelajaran yang didapat oleh peneliti yaitu pada kriteria keaktifan diperoleh skor 4, kerjasama diperoleh skor 3, Kesungguhan skor 4, dan percaya diri diperoleh skor 3. Sehingga persentase keberhasilan siswa dalam sikap belajar sebesar 87,5\%. Selain dari lembar observasi siswa juga dilakukan melalui tes gerak dasar lari jarak pendek. Berikut hasil tes gerak dasar lari jarak pendek pada siklus 2:

Tabel 5. Hasil Pengamatan Pada Siklus II : Lari Jarak Pendek

\begin{tabular}{|l|c|c|}
\hline \multicolumn{1}{|c|}{ Kriteria } & Jumlah sisa & Persentase (\%) \\
\hline Tuntas & 17 & $85 \%$ \\
\hline Tidak Tuntas & 3 & $15 \%$ \\
\hline Jumlah & 20 & $100 \%$ \\
\hline
\end{tabular}

Dari hasil tes tahap siklus II yaitu terdapat 17 siswa yang memiliki kriteria tuntas dengan persentase $85 \%$ dan sebanyak 3 siswa (15\%) yang belum memenuhi kriteria ketuntasan minimal. Hasil tersebut menunjukkan bahwa nilai tuntas siswa belum mencapai nilai indikator keberhasilan dalam pembelajaran. Hasil ini juga disimpulkan bahwa hasil pembelajaran gerak dasar lari jarak pendek siswa SD Negeri 62 Kota Bengkulu mengalami peningkatan. Oleh karena itu, penerapan model demonstrasi mampu menyelesaikan masalah tersebut dan dapat meningkatkan

18 | Reza Kurnia Sandi, Tito Parta Wibowo; Efforts To Improve Basic Movement... 
gerak dasar lari jarak pendek Siswa kelas V SD Negeri 62 Kota Bengkulu. Untuk lebih jelasnya dapat dilihat dari grafik di bawah ini:

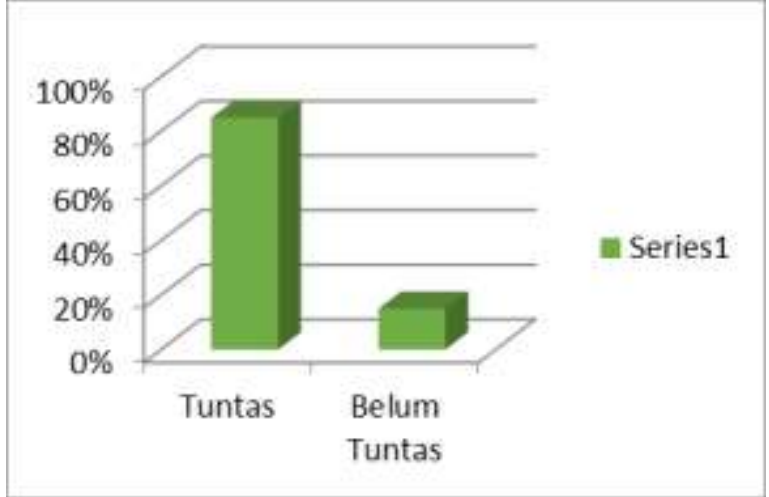

Refleksi

\section{Gambar 3. Hasil Tes Gerak Dasar Lari Cepat Pada Tahap Siklus II}

Dari hasil tes Gerak dasar lari jarak pendek menunjukan bahwa hanya 17 siswa dinyatakan memenuhi KKM ketuntasan dan 3 siswa dinyatakan tidak memenuhi KKM ketuntasan. Berdasarkan hasil observasi juga menunjukan bahwa pembelajaran gerak dasar lari jarak pendek melalui penerapan metode demonstrasi pada siklus 2 ini sudah maksimal.

Berdasarkan hasil kolaborasi antara peneliti dan kolabolator serta hasil evaluasi proses kegiatan belajar mengajar yang dilakukan siswa kelas $\mathrm{V}$ pada siklus II didapatkan hasil refleksi sebagai berikut: (1) Siswa dapat melakukan teknik dasar keterampilan gerak dasar lari cepat pada pembelajaran Atletik dengan baik, (2) Siswa tidak kaku dalam melakukan teknik dasar keterampilan gerak dasar lari cepat pada pembelajaran Atletik, (3) Sikap awalan, pelaksanaan, dan sikap akhir dalam melakukan keterampilan gerak dasar lari cepat pada pembelajaran Atletik, (4) Berdasarkan pada pelaksanaan penerapan metode demonstrasi telah dicapai pada dua siklus yaitu siklus I dan II dan telah menunjukkan adanya peningkatan keterampilan gerak dasar lari cepat pada pembelajaran Atletik.

Berdasarkan data analisis di atas, peneliti menemukan beberapa hasil penelitian yang menjawab rumusan masalah yang akan dijelaskan sebagai berikut: apakah penerapan motode demonstrasi dapat meningkatkan keterampilan gerak dasar lari jarak pendek pada siswa kelas V SD Negeri 62 Kota Bengkulu. Diagram di bawah ini menunjukkan peningkatan frekuensi ketuntasan siswa pada tahap prasiklus, siklus I, dan siklus II.

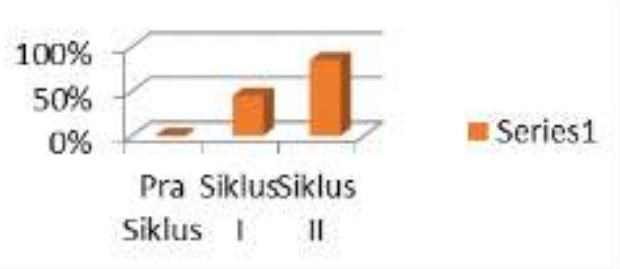

\section{Gambar 4. Rekapitulasi Peningkatan Keterampilan Gerak lari jarak pendek dengan Model Demonstrasi Pada Siswa kelas V di SD Negeri 62 Kota \\ Bengkulu}

Perhentian Siklus

Dengan melihat dari hasil tindakan pada siklus II, dapat diketahui bahwa dari 20 siswa telah dicapai $85 \%$ siswa berhasil memenuhi kriteria ketuntasan minimal. Maka dengan demikian penerapan metode demonstrasi dalam meningkatkan keterampilan 
gerak dasar lari jarak pendek pada siswa kelas V SD Negeri 62 Kota Bengkulu telah dicapai oleh siswa dan telah memenuhi kriteria ketuntasan minimal, hal ini menunjukkan bahwa penguasaan siswa terhadap keterampilan gerak dasar lari jarak pendek dalam pembelajaran atletik sebesar $85 \%$ siswa tuntas.

\section{Pembahasan}

Berdasarkan prosedur tindakan kelas yang dirancang dan dilaksanakan dengan sistematis dan terencana dengan baik, maka peneliti dapat mengumpulkan data-data penelitian yang merupakan informasi penting hasil penelitian. Dari hasil penelitian ini dibandingkan dengan teori-teori serta ide-ide yang dijelaskan pada kajian pustaka, pada penelitian tindakan kelas ini telah membawa dampak yang positif terhadap peningkatan keterampilan gerak dasar lari cepat pada pembelajaran atletik metode demonstrasi.

Dari hasil nilai rata-rata siswa pada pra siklus dengan pencapaian persentase sebesar $0 \%$ meningkat di siklus 1 mencapai 45\%. Dari hasil ini terdapat suatu peningkatan yang baik jumlah ketuntasan siswa dalam pembelajaran ini. Peningkatan tersebut mencapai $45 \%$ dan selain dari hasil tes keterampilan gerak dasar lari jarak pendek, dilihat juga dari observasi sikap siswa selama pembelajaran berlangsung yang didapat oleh peneliti yaitu: pada observasi siklus 1 sebesar $68,75 \%$ dari skor maksimal masuk dalam kategori cukup. Berdasarkan penjelasan dari hasil lembar observasi sikap siswa pada siklus 1 tersebut, dapat disimpulkan bahwa pembelajaran atletik pada kompetensi dasar keterampilan gerak dasar lari jarak pendek belum mencapai indikator keberhasilan dan masih perlu ditingkatkan pada siklus berikutnya.

Pada siklus II nilai rata-rata hasil tes keterampilan gerak dasar lari jarak pendek mencapai $85 \%$. Hal tersebut menunjukkan bahwa adanya peningkatan sebesar $40 \%$ dari hasil tes keterampilan gerak dasar lari jarak pendek. Dan dari observasi sikap siswa yang didapat oleh peneliti yaitu; sikap siswa pada kriteria keaktifan, percaya diri, kesungguhan dan tanggung jawab diperoleh persentase sebesar 87,5\% dari skor maksimal ini berarti sikap siswa selama pembelajaran berlangsung sangat baik. Berdasarkan penjelasan dari hasil lembar observasi sikap siswa pada siklus 2 di atas, dapat disimpulkan bahwa pembelajaran atletik pada pokok bahasan keterampilan gerak dasar lari cepat sudah mengalami peningkatan, dan mampu mencapai indikator keberhasilan pada penelitian ini. Selain itu, hasil dari observasi telah memuaskan sehingga penelitian dapat dihentikan pada siklus ini. Hal ini sesuai dengan Metode demonstrasi adalah metode mengajar dengan cara memperagakan barang, kejadian, atau aturan, serta melakukan sesuatu kegiatan baik secara langsung maupun melalui media pengajaran yang relevan dengan pokok bahasan atau materi ( Syah dalam Setyanto, 2017: 172). Sedangkan menurut Roestiyah (2008: 83) teknik demonstrasi mempunyai tujuan agar siswa mampu memahami tentang cara mengatur atau menyusun sesuatu.

\section{KESIMPULAN}

Dari hasil penelitian yang telah dilakukan melalui penerapan metode demonstrasi sangat efektif dalam meningkatkan keterampilan gerak dasar lari jarak pendek siswa kelas V SD Negeri 62 Kota Bengkulu. Adapun persentase peningkatan ketuntasan minimal pada pra siklus sebesar $0 \%$, meningkat menjadi $45 \%$ pada tahap Siklus I dan meningkat menjadi $85 \%$ pada siklus II. Hal ini menunjukkan bahwa metode demonstrasi dapat dikatakan berhasil meningkatkan keterampilan gerak dasar lari jarak pendek pada pembelajaran Atletik. 


\section{SARAN}

1. Guru pendidikan jasmani olahraga dan kesehatan dapan menerapkan metode demonstrasi dalam pembelajaran lari pada siswa kelas V di SD Negeri 62 Kota Bengkulu.

2. Penerapan metode demonstrasi juga direkomendasikan untuk membantu guru dalam menumbuhkan kegembiraan dan percaya diri pada siswa serta dapat memotivasi siswa dalam proses belajar mengajar PJOK.

3. Penelitian selanjutnya sangat direkomendasikan guna menemukan sebanyak mungkin model permainan dalam pembelajaran yang dapat meningkatkan keterampilan dasar siswa dalam pembelajaran lari.

\section{DAFTAR PUSTAKA}

1. Agus Kristianto. A. 2010. Penelitian Tindakan Kelas. Surakarta: Sebelas Maret University Press.

2. Dewi, Setiawati. 2016. Guru Pembelajar Penjas. Jakarta: Dirjen GTK Kemendikbud.

3. Engkos, Kosasih. 2005. Pendidikan Jasmani dan Kesehatan. Jakarta: Penerbit Erlangga,

4. Fenanlampir, A.,dan Faruq M,. 2015. Tes dan Pengukuran Dalam Olahraga. Yogyakarta: CV. Andi Offset.

5. Hamalik, Oemar. 2013. Proses Belajar Mengajar n.( Jakarta : PT.Bumi Aksara )

6. Harsuki. 2003. Perkembangan Olahraga Terkini : Kajian Para Pakar. Jakarta: PT Raja Grafindo Persada.

7. Muhajir. 2013. Pendidikan Jasmani Olahraga dan Kesehatan XI. Bandung : Erlangga.

8. Muhamad Djumidar. 2004. Gerak-Gerak Atletik Dalam Bermain. Jakarta: PT. Raja Grafindo Persada.

9. Pendidikan dan kebudayaan, direktorat Pendidikan Dasar dan Menengah, Direktorat Pendidikan Guru dan Tenaga Teknis Bagian Proyek Penataran Guru Pendidikan Jamani dan Kesehatan SD Setara D II.

10. Purnomo. E. \& Dapan. 2011. Dasar-Dasar Atletik. Yogykarta: Alfamedia.

11. Roestiyah, N.K. 2008. Strategi Belajar Mengajar. Jakarta: Rineke Cipta.

12. Setyanto. Ardi. 2017. Interaksi dan Komunikasi Efektif Belajar mengajar. Yogyakarta: DIVA Press

13. Sudjono. 2007. Metodologi Penelitian Pendidikan. Jakarta: Rineka Cipta.

14. Sukintaka . 2004 Tujuan Pendidikan Jasmani. Jakarta: DepDikBud

15. Suyanto dan Djihad Asep. 2013. Bagaimana Menjadi Calon Guru dan Guru Profesional. Yogyakarta: Multi Pressindo.

16. Trianto. 2011. Penelitian Tindakan Kelas. Jakarta: Prestasi Pustakarya. 